\title{
Freud, Lacan e o Conto da Ilha Desconhecida - Reflexões Psicanalíticas Acerca de um Conto de Saramago
}

Freud, Lacan and the tale of the unknown Island psychoanalytical examinations on a tale of José Saramago

Frederico Teixeira Gorski

Universidade Federal de Santa Catarina 


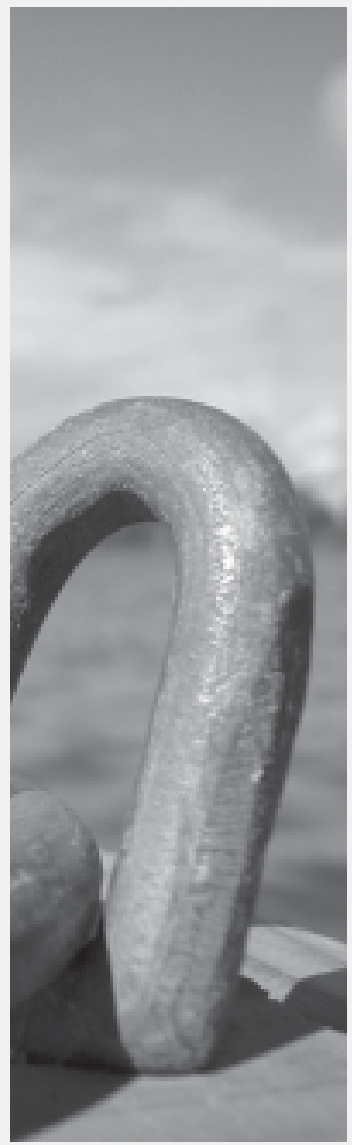

Resumo:O presente artigo tem por finalidade trabalhar, através da interpretação das simbolizações em um conto de José Saramago, alguns conceitos psicanalíticos firmados por Lacan e por Freud. Para tanto, discute o texto em unidades de significação e identifica os processos simbólicos aí envolvidos com as teorias daqueles psicanalistas. O resultado é uma interpretação da simbolização de um desejo a ser realizado - a saber, a reintegração com a mãe - como significado do conto.

Palavras-chave: literatura e Psicanálise, Saramago, subjetividade.

Abstract:The present article aims to work on some psychoanalytical concepts proposed by Freud and Lacan. This is done through the interpretation of the symbolizations found in a tale of José Saramago. The text is divided in signification unities and the symbolical processes of these unities are identified with the theories of those psychoanalysts. The result is an interpretation of the tale as the symbol of the desire to become one with the mother.

Key words: literature and Psychoanalysis, Saramago, subjectivity.
É Freud quem diz, na Traumdeutung (1999), que a interpretação de um sonho nunca tem fim. Não quis dizer, com isso, que a interpretação de um sonho seja inútil, pois, bem o sabemos, é possível que ela seja coerente, bem acabada e sempre útil na medida em que possibilite o processo de elaboração do paciente. Sua intenção, quando assim se expressou, era a de que tivéssemos em mente que, por mais que o façamos e pareça-nos uma interpretação correta, não devemos acreditar em tal coisa. Um mesmo sonho, dizia ele, pode ser interpretado pelo mesmo analista, ou por outro, de várias formas. Qual delas, então, será a mais correta? Nenhuma e todas - é o que ele, arrisco a dizer, responderia. É que toda interpretação, como Lacan diria das pulsões, é parcial, fragmentária, e, embora possa trazer uma visão muito global do sonho, deixa sempre algo escapar. Prova disso é que, em um sonho, existem aqueles "fragmentos" que não conseguimos interpretar, os quais Freud denominava o umbigo dos sonhos. Mas esse umbigo poderia ser posteriormente desvelado, e, mesmo assim, achar-se-iam outros umbigos, isso ao infinito ${ }^{1}$. Por outro lado, sonhos que outrora não nos pareceram decifráveis podem vir a sê-lo em outras épocas.

Tal como Freud encarou os sonhos, quisemos também, depois de já o ter feito de outras formas, lançar um olhar psicanalítico sobre esse conto de Saramago. Eis o motivo pelo qual o escolhemos para este artigo. Como
1 Essas reflexões podem muito bem remeter-nos à questão da cientificidade da Psicanálise. Diríamos, aqui, que uma interpretação é válida e verificável na medida em que seus elementos são apresentados $e$ relacionados, e, nesse sentido, é passivel de verificação por outro analista ou qualquer pessoa que se deite aos estudos de Psicanálise. Não obstante, ela pode ser ampliada ou observada sob outro aspecto que, pelos motivos já expostos, será complementar a ela. 
outras histórias do escritor português, O Conto da Ilha Desconhecida nos oferece, ou melhor, é rico em metáforas - e ele mesmo (o conto) é uma delas - que abrangem diversos assuntos. Assim, ao adotar a Psicanálise e, mais precisamente, a perspectiva lacaniana, não podemos deixar de assinalar que ela (a interpretação) é limitada - os motivos que nos levam à conclusão são os já expostos - mas também incansável e irresistível, pois pode servir de matéria, ela mesma (como o foram as interpretações de Freud) para outros estudos e reflexões.

O presente texto foi inicialmente escrito para a disciplina Jacques Lacan, ministrada pelo prof. Sérgio Scotti, na Universidade Federal de Santa Catarina, ao final de agosto de 2002. Sua redação serviu para ampliar a compreensão sobre os textos do psicanalista francês, mas o resultado obtido pareceu-nos ir além do esperado, pelo que, após seis meses, decidimos revisitá-lo, corrigi-lo e ampliá-lo para esta publicação. Não obstante, cuidamos de não abusar dos jargões lacanianos que, ao leitor leigo, só dificultariam a compreensão do texto. Tampouco abusamos das citações aos textos do psicanalista francês, antes procuramos referir-nos às suas idéias, em geral ligando-as àquelas de Freud, coisa que, cremos, seria de agrado do "criador" do Nome-do-Pai. Acreditamos que também àqueles habituados à leitura dos textos de Lacan este artigo parecerá bastante agradável e satisfatório. Dizemos satisfatório em relação às conclusões e derivações que fizemos das idéias daquele psicanalista.

Referente ao texto de Saramago, não vamos ater-nos aos elogios, pois seriam muitos. Não preparamos um resumo da obra, pois julgamos que a discussão traria suficiente informação descritiva; de outra forma, a leitura do original é sempre mais indicada.

Antes de passar à discussão, queremos ressaltar que este texto não é uma análise do autor, mas um trabalho que visa à discussão crítica das teorias psicanalíticas, mais particularmente, de Freud e Lacan. Nenhum esforço foi feito no sentido de buscar dados biográficos do autor, antes de tudo, porque não cremos que seria muito ético acreditamos ser desnecessária uma explicação a respeito. Assim, são as simbolizações dentro do contexto da obra que aqui se trabalham no sentido de propiciarem novos horizontes para os trabalhos no campo de literatura e Psicanálise, à maneira mesmo que Freud e Lacan fizeram em seus trabalhos sobre Édipo, Hamlet e A Carta Roubada, todas essas análises já consagradas.

Cremos que é tudo que temos a dizer. Ao leitor, que, sobretudo, Ihe seja agradável acompanhar-nos.

\section{Discussão}

Todo texto de Saramago é desenvolvido de maneira bastante peculiar. Em seus livros mais volumosos, não há uma separação entre capítulos - eles não são nomeados, pelo menos - embora alguns trechos apareçam separados. É como se nos dissesse: Tome, leia isso por hoje. E são de vinte a quarenta páginas, em geral.

Nesse texto que queremos analisar, isso não ocorre, pela sua própria extensão. A mensagem, aqui, é outra, algo como: tome, leia isso hoje; amanhã, torne a lê-lo, se gostar. Ainda assim, julgamos melhor separá-lo em trechos pequenos, nomeando cada um desses. É uma divisão que só serve para facilitar a análise. Ao leitor não acostumado com os textos do escritor português, parecerá estranho afirmar que baseamos nossa "capitulação" do livro pelos parágrafos nele contidos. É que, nessa obra, como em outras do mesmo autor, cada parágrafo equivale a uma unidade do livro.

Passaremos, então, à análise, primeiro de forma "fragmentada" e, após, na conclusão, 
a uma avaliação final dos resultados obtidos - é dizer, uma análise geral.

\section{A casa do rei}

O conto se passa em um reino que, em outras épocas, parece ter sido uma grande potência marítima. Não sabemos há quanto tempo foi isso, nem mesmo em que época agora nos encontramos. Aqui e ali, no entanto, percebemos uma semelhança com a terra natal do escritor ${ }^{2}$. O que não chega a ser muito saliente pode ser notado pelo uso de expressões como "mar tenebroso" expressão essa utilizada, como sabemos, na época das grandes navegações.

"Um homem", então, "foi bater à porta do rei e disse-Ihe, Dá-me um barco" (Saramago, 1998, p.5).

Há, aqui, algo que chama a atenção. Em nenhum lugar do mundo, um súdito vai bater à porta do rei para dizer-lhe, imperativamente: Dá-me um barco. É importante assinalar, contudo, que qualquer interpretação prévia dessa frase seria prematura. $O$ mais interessante seria ater-se a um significante que servisse de fio condutor de boa parte do conto, a saber, o barco.

A casa do rei tinha muitas portas, a das petições, à qual o homem foi bater, a dos obséquios, aonde se encontra o rei para recebê-los (os obséquios), a das decisões, etc... Quando alguém vem bater à porta das petições, o rei faz-se de desentendido, e só quando o barulho da aldraba se torna insuportável, o povo já se encontra a comentar-Que rei temos nós, que não atende (p.5) - é que o rei ordena ao primeirosecretário ir abrir a porta, este repassa a ordem ao segundo-secretário, que a repassa ao terceiro, deste para o primeiro-ajudante, e por aí afora, até a mulher da limpeza, que abre a porta e pergunta: Que é que tu queres?
Esse movimento, ao qual Freud, na Interpretação dos Sonhos, dará o nome de deslocamento, Lacan denominará metonímia, quer dizer, aquilo que é próprio de um personagem é incumbido a outro, o que desse agora se tem por propriedade é atribuído a outro, e assim por diante, como num texto em que se começa por tentar definir um termo, que, nesse processo, será associado a outro, e daí ao infinito. Assim, o que era antes uma responsabilidade do rei - a população gritava, Que rei temos nós, que não atende foi sendo atribuído a outros personagens que, por sua vez, repassaram-na a outros. Quando chega à mulher da limpeza, o processo encontra o seu fim, mas será retomado pela inserção de um outro significante, que passará a exercer a mesma função do primeiro (a ordem do rei). Vejamos como isso ocorre:

O suplicante dizia ao que vinha, isto é, pedia o que tinha de pedir, depois instalava-se a um canto da porta, à espera de que o requerimento fizesse, de um em um, o caminho ao contrário, até chegar ao rei (Saramago, 1998, p. 6).

O requerimento do suplicante, pois, será o novo significante que conduzirá o processo metonímico. E há que se notar algo. Qual é a função do rei? O rei tem, precisamente, uma função, e não é aquela de ficar sentado a uma porta a receber coisas. Pelo contrário, isso só é permitido ao rei porque ele atende a seus súditos quando esses vêm bater à porta das petições. Pois bem, se a função do rei é essa que vai sendo repassada de personagem em personagem, quando chega à mulher da limpeza, o que a princípio seria também função daquele - receber o pedido - já está atribuído à mulher, que o repassará aos outros personagens, até que estes o passem ao rei, e assim vai... (não se trata, contudo, de transferência entre os personagens). Retomaremos esse tópico ao final de nossa explanação, pois o rei tem, por detrás disso que assinalamos, ainda uma outra função.
"Um homem", então, "foi bater à porta do rei e disse-lhe, Dá-me um barco" (Saramago, 1998, p.5).

2 Importante lembrar que essa análise se limita ao texto, sem estender-se a vida pessoal do autor. Não obstante, a marcação dessa referência parece-nos relevante, na medida $\mathrm{em}$ que pode remeter a um estudo posterior que ligue q que aqui se revela com a realidade sociopolíticoeconômica da sociedade contemporânea. Estamos, afinal, consciente da inserção política das obras saramagueanas. 
Desse capítulo, o que temos, portanto, é a identificação de um significante, o barco; de um processo de deslocamento, ou metonímico; de uma função a ser descoberta.

\section{O caso do homem que queria um barco}

"Contudo, no caso do homem que queria um barco, as coisas não se passaram bem assim" (p. 9). Nesse caso, o homem, ao invés de pedir o que queria, disse à mulher da limpeza: Quero falar ao rei. Dessa maneira, o que, a princípio, pareceria um simples requerimento, parece romper a ordem até então vigente. A mulher não faz, como de costume, o pedido retornar pelas vias burocráticas competentes, antes adverte o transeunte de que o rei não poderá vir atendê-lo. O homem insiste: "Pois então vá lá dizer-lhe que não saio daqui, até que ele venha, pessoalmente, saber o que quero" ( $p$. 9). A mulher repassa o pedido, enquanto o homem se ajeita a um canto da porta, à espera. Nesse meio tempo, ninguém poderá pedir coisa alguma.

Ao rei, foi um breve instante de prazer, em que o afluxo de obséquios que recebia não foi interrompido pela inoportuna intromissão de um súdito a pedir-lhe algo. Por outro lado, ao cabo de alguns dias, o descontentamento social cresceu e teve o rei de ir, em real pessoa, atender aos chamados.

Tomemos uma expressão que vem entre vírgulas, no texto original, e que quisemos aqui conservar para mostrar a sua sutileza. O rei vem, pois, em real pessoa, quer dizer, o rei foi incomodado porque esteve a se regozijar com o que recebia - que não sabemos o que era mas foi incomodado porque, em um dado ponto, uma certa pessoa fez com que a atenção dada ao rei tivesse de ser desviada. Por isso, é o que se pensa, virá à porta das petições com um ar autoritário, ar daquele que conhece a lei. Ou melhor, que tem a lei.
Que sucede, então? O rei pede à mulher que abra a porta, mas não sabe se quer que a abra só um pouco, ou toda. Se a abrir pouco, dará ao povo o que falar. Afinal, que rei é esse que tem medo de encarar um súdito? Se abrir a porta bem aberta, terá de se expor aos transeuntes que ali já se amontoavam - uns por curiosidade, outros ansiando pela liberalidade do lugar em que se encontra o homem que veio pedir um barco. Resolve abrila de par em par. Já o homem que esperava não se alterou em demasia. Juntou suas coisas, levantou-se e pôs-se a aguardar o rei.

“Esses sinais de que finalmente alguém vinha atender, e que portanto a praça não tardaria a ficar desocupada, fizeram aproximar-se da porta uns quantos aspirantes à espera da liberalidade do trono [...]" (p.12).

Ora, dizer que aguardavam pela "liberalidade do trono" é o mesmo que dizer que aquele que ali se acostar, exerce, decerto, um grau de poder sobre o rei. Vejamos, então, o que se passa a seguir.

"[...] o rei, com o pior dos modos, perguntou três perguntas seguidas, Que é que queres, Por que foi que não disseste logo o que querias, Pensarás tu que eu não tenho mais nada que fazer [...]" (p.15).

Mas o homem, que, como já vimos, não se havia abalado, respondeu apenas: Dá-me um barco. O rei, desajeitado com a audácia, não propriamente do pedido, mas da entonação - é isso que o narrador dá a entender, e isso permite concluir que é pelo "correto" uso do significante que o rei pensa "esse homem sabe" - perde o equilíbrio, e a mulher da limpeza apressa-se em acercar-lhe uma cadeira. Essa cadeira, ao rei, era incômoda. Era mais baixa que o trono e servia à mulher para que realizasse outras tarefas, como passajar as peúgas dos pajens (p.16). São essas as palavras que usa o narrador e é, sobretudo, muito interessante que as utilize. Queremos chamar a atenção para a última delas e 
assinalaremos alguns de seus significados, inclusive o etimológico.

A palavra pajem é de origem francesa e significa, etimologicamente, jovem rapaz. Era utilizada para designar aqueles que acompanhavam um senhor feudal ou príncipe em uma viajem; o pajem era um iniciante nas carreiras das armas. Um outro significado é o de menino que integra o cortejo matrimonial. Como se trata de monarquia, o provável é que o significado etimológico sirva melhor. Contudo, o fato de que não se trata, aqui, de um castelo do rei, mas de uma casa do rei, o que faz uma certa diferença, leva-nos a crer que haja crianças na casa. A mulher da limpeza, por conseguinte, não tem apenas aquela função que já conhecemos, mas também cuida das crianças.

Retornemos à história. O rei pergunta ao homem porque é que ele queria um barco, ao que o homem lhe responde: Para ir em busca da ilha desconhecida. O rei, contendo o riso, pergunta-lhe: "Que ilha desconhecida?" (p.17). E é como se não entendesse - ilha desconhecida?, não sabeis que já não as há? $\mathrm{O}$ homem repete que quer ir à ilha desconhecida. Parece que, aí, um dos dois não sabe bem do que fala o outro. Precisamente, pode-se assinalar nesse instante, no texto, o surgimento de outro significante que, como o leitor, pelo título da obra, já deve ter deduzido, será de fundamental importância: a ilha desconhecida. Mas é importante, antes de tudo, apontar o fato de que a ilha desconhecida não tem, para os dois homens, o mesmo significado. Se nos ativermos ao detalhe, veremos que, pela própria expressão, os significados empregados possuem uma relação profunda, mas a diferença, apesar de sutil, é também significativa. Enquanto o rei fala das ilhas existentes (das conhecidas), assinalando que tudo se conhece e que, por via lógica, não há ilhas desconhecidas, o homem do barco fala de uma outra ilha, que está sempre desconhecida e que nunca deixará, a rigor, de o ser. Não é de se espantar que esse diálogo produza o efeito que produz, ou seja, de separação de significante e significado. Se Saussure (1992) nos ensina que o significante é arbitrário e que um significado possui vários significantes, o narrador, aqui, nos deixa a certeza de que o significante pode, ele também, em dialetos diferentes, possuir significados distintos ${ }^{3}$. Os homens, pois, estão a falar dialetos distintos, mas de um mesmo idioma.

"Disparate", diz o rei, "já não há ilhas desconhecidas" (Saramago, 1998, p.17).

Ao que o homem contesta: "Quem foi que te disse, rei, que já não há ilhas desconhecidas" (p.17).

Ora, isso é lógico. Como se pode dizer, com absoluta certeza, que já não há coisas por se conhecer? As ilhas do mapa, diz o homem mais adiante, só estão no mapa porque são conhecidas; as ilhas desconhecidas, se lá estivessem, não o seriam. Queremos chamar a atenção para um detalhe que já foi apontado há muito tempo, por um filósofo, a quem se atribui a descoberta do inconsciente, muito antes de Freud também bater nessa tecla: é Leibniz (apud. Mueller, 1978; Hergenhahn, 1986). Para ele, toda coisa que fosse apercebida, ou melhor, toda apercepção era acompanhada por inúmeras percepções difusas que não apreendemos - por isso, não apercebidas - e que podem se tornar apercebidas algum dia, mas, em todo o caso, sempre haverá percepções difusas. É recomendado marcar, porém, que o inconsciente freudiano difere do de Leibniz ${ }^{4}$. Isso não quer dizer que não possamos dizer que haja Leibniz na empresa de Freud.

Temos, pois, um significante, e parece que alguém sabe o que é esse significante, o que há por detrás dele. É o que parece.
3 Apenas para mostrar como o tema da interpretação é infinito, podemos, aqui, tomar o texto sob outro viés. Diríamos, então, que Saramago, por meio desse diálogo, representa o neurótico, que é aquele que "quer" a realidade, de acordo com Freud, e o psicótico - aquele que "quer" a realidade como o espelho de seu desejo. também de acordo com psicanalista austríaco.

4 Ao contrário do que se diz. Leibniz não elaborou uma psicologia do inconsciente, nem se the pode atribuir uma invenção do inconsciente como entidade psíquica. Antes, sua contribuição para a Psicologia se deve ao fato de que ponderou a existência de fenômenos que não atingem a percepção consciente humana, e, para isso, elabora sua teoria das mônadas. Para que um determinado fenômeno viesse à consciência, seria necessário um número determinado de mônadas. $O$ termo inconsciente em Freud (1999b, pp. 264 266), por outro lado, aparece de duas formas distintas: uma em que aparece como um adjetivo para as funções e processos mentais; a rigor, nos diz ele, todo processo mental é inconsciente, posto que estamos conscientes apenas de seus resultados, mas não exatamente de suas causas especificas, $e$ outro uso é o de inconsciente como um substantivo. Esse é o caso para o primeiro tópico, em que aparece como uma instância psíquica que, a priori, não podemos acessar por inteiro. 
Ora, o homem quer um barco, dê-lhe um barco. É o desejo que as pessoas, como elemento do sonho, querem realizar, desejo que, aqui, aparece como desejo do Outro.
Segue a discussão sobre a ilha desconhecida, o homem esclarecendo ao rei que a ilha desconhecida é, por definição, desconhecida a todos. O rei aceita o desafio e pergunta:

"E vieste aqui para me pedires um barco, Sim, vim aqui para pedir-te um barco, E tu quem és para que eu to dê, E tu quem és, para que não mo dês, Sou o rei deste reino, e os barcos do reino pertencem-me todos" (pp. 17-18).

E aí o homem joga sua boa carta: "Mais lhes pertencerás tu a eles do que eles a ti" (p.18). Como assim?, pergunta o rei. Que é um rei sem barcos? Ainda mais em um país cuja potência se dá por sua potência marítima. Justamente, o rei só é rei porque tem barcos, mas os barcos, esses, sem o rei, podem sempre navegar. O rei, então, pergunta-Ihe se essa ilha, quando for encontrada, será dele. Mas só as ilhas conhecidas interessam ao rei. A ele, as ilhas desconhecidas só interessam quando deixam de o ser. "Talvez esta não se deixe conhecer, Então não te dou barco, Darás" (p. 18).

É digno de nota o que se passa a seguir. As pessoas que, até então, assistiam ao colóquio, resolvem intervir, aos gritos de - Dá lhe um barco, dá-lhe um barco (p.19).

Quando o rei quer intervir, as pessoas gritam mais alto - Dá-Ihe um barco... (p.19).

Ora, o homem quer um barco, dê-lhe um barco. É o desejo que as pessoas, como elemento do sonho, querem realizar, desejo que, aqui, aparece como desejo do Outro.

O rei, perante a manifestação popular, resolve levantar a mão, pedir silêncio e dizer: "Vou dar-te um barco" (pp.19-20). Indicou ao homem o que fazer - Vais à doca, perguntas lá pelo capitão [...] (p.20) - e entrega-lhe um cartão. No cartão, dizia Rei, por baixo do nome do rei, e as seguintes palavras se encontravam inscritas: "Entrega ao portador um barco, não precisa ser grande, mas que navegue bem e seja seguro, não quero ter remorsos na consciência se as coisas lhe correrem mal" (p.23). Observemos quão bondoso é esse rei que se encherá de remorsos de acontecer algo de ruim a esse "insolente". $\mathrm{O}$ rei sai sem que o homem veja, a mulher está a olhá-lo com cara de caso. Ele desce o degrau da porta, a porta se fecha, a aldraba torna a tocar, mas a mulher da limpeza já não está; saiu pela porta das decisões, que é raro ser usada, mas quando o é, é. Agora sabemos porque a mulher estava a olhar o homem. Já bastava de uma vida a limpar e a lavar palácios, seu ofício era limpar e lavar barcos. Quando narramos o que se passa na história, procuramos manter algo do estilo de Saramago, e, quando não é possível, o autor é citado. É um estilo muito agradável de se ler. Por isso, iremos fechar este capítulo com mais uma citação. Antes, contudo, queremos deixar apontados os significantes que importaram realmente, nesse capítulo. São eles: 1) o barco; 2) a ilha desconhecida; 3) a mulher da limpeza; 4) o cartão do rei.

Dito isso, eis como termina o caso do homem que queria um barco:

O homem nem sonhe que, não tendo ainda sequer começado a recrutar os tripulantes, já leva atrás de si a futura encarregada das baldeações e outros asseios, também é deste modo que o destino costuma comportar-se connosco(sic), já está mesmo atrás de nós, já estendeu a mão para tocar-nos o ombro, e nós ainda vamos a murmurar, Acabou, não há mais que ver, é tudo igual (p.24).

\section{O barco da mulher da limpeza}

No famoso Discurso de Roma, também conhecido como função e campo da palavra e da linguagem em Psicanálise, Lacan comenta o ato falho:

Quanto à Psicopatologia da vida cotidiana, outro campo consagrado por outra obra de 
Freud, é claro que todo ato falho é um discurso bem-sucedido, e que o lapso é a mordaça que gira em torno da palavra e justo ao quadrante que faz falta para que um bom entendedor encontre aí sua meia-palavra (Lacan, 1984, p. 258).

Se não podemos encontrar, no trecho do livro de Saramago acima citado, uma meia palavra, é porque aí não houve uma mordaça que se sobrepusesse justo ao momento em que poderíamos decifrá-la, pelo contrário, é o discurso mais do que bem sucedido que encontramos. Veja o leitor que ele narra o evento como se o homem que veio pedir um barco, e que agora o tinha, tivesse, apesar de tudo, saído derrotado - e por que não acrescentar, sentindo-se derrotado?

O homem foi à doca, portanto, com a mulher a suas costas, fato que, é sempre importante lembrar, ele não sabia. Ao capitão, tiveram de mandar buscar, e ele se perguntava qual seria o barco que receberia. Nem grande nem pequeno, o rei tinha sido categórico, mas que pudesse navegar em mar alto. A mulher, para trás, escondida estava, e a observar qual dos barcos queria: "Para o meu gosto, aquele, pensou [...]" (Saramago, 1998, p.26).

Quando o capitão chegou e mirou o homem de alto a baixo, fez a pergunta que o rei não havia feito - Sabes navegar, tens carta de navegação (p. 26). O homem respondeu que aprenderia no mar, ao que o capitão advertiuIhe que no mar é que não se aprendia, não com qualquer barco. Disse o homem: "Dá- me então um com que possa atrever-me eu, não, um desses não, dá-me antes um barco que eu respeite e possa respeitar-me a mim" (p.26).

O capitão comenta que essa linguagem é de marinheiro, e o homem coloca que, se tinha a linguagem, era como se o fosse.

A linguagem, que, em Lacan, será recobrada em sua função essencial dentro da Psicanálise. A famosa expressão o inconsciente é estruturado como uma linguagem pode parecer aqui inapropriada, posto que o "o fosse" pressupõe o eu cartesiano que, como pensasse, então era. Mas diríamos, aqui, que o leitor toma as palavras ao pé da letra, pois a linguagem não deixa de ser onde o desejo se expressa de forma simbólica, quer dizer, se fala como marinheiro, é porque o deseja ser, e se deseja - crê - é como se o fosse.

O capitão torna a ler o cartão do rei e pergunta para que quer ele um barco. Já vem aí devolvido o tema da ilha desconhecida, que os homens, afinal de contas, parecem sempre esquecer do que significa. Vejamos um trecho dessa conversa:

“[...] Já não há ilhas desconhecidas, O mesmo me disse o rei, $\mathrm{O}$ que ele sabe de ilhas, aprendeu-o comigo [...]" (p.27). O homem que queria um barco diz que Ihe soa estranho que, o capitão sendo homem do mar, não o saiba já, que ilhas desconhecidas sempre há de haver, e que, ademais, as ilhas conhecidas são sempre desconhecidas enquanto ainda não desembarcamos nelas. Parece que a função do rei que era, em um primeiro momento, a de impedir o homem de ir em busca da ilha desconhecida, foi repassada ao capitão. Como o discurso do capitão reincide nessa temática, o homem muda o seu.

O capitão ainda insiste que, parecia-lhe, a ilha que o homem andava a procurar era uma em que ninguém havia desembarcado antes. Saberá quando lá chegar, responde o homem. E o capitão: se chegares (p.27). Mas, em última análise, recorda o homem do barco, sempre se chega.

Queremos mostrar o diálogo que se segue: “O capitão do porto disse, Vou dar-te a embarcação que te convém, Qual é ela, É um barco com muita experiência, ainda do tempo em que toda a gente andava à procura de ilhas desconhecidas, Qual é ele, Julgo até que encontrou algumas, Qual, Aquele" (p.28).
5 As traduções livres são de nossa autoria. 
Pedimos ao leitor que preste bastante atenção a essas frases, relembre o que falamos anteriormente e acompanhe-nos agora, pois iremos continuar e deixar para depois a interpretação.

O barco, por um acaso, era aquele mesmo que a mulher da limpeza havia escolhido. $\mathrm{E}$ ela sai a gritar - É o meu barco, é o meu barco. É o mais recomendável quando se vai em busca de ilhas desconhecidas, lembra o capitão. E a mulher da limpeza, aproximandose: "Para mim não quero outro" (p.31).

O homem não se recorda da mulher, mas logo se entendem, combinam, então, que ela irá cuidar do barco, enquanto ele cuidará da tripulação.

Ela ainda pergunta se ele não gostaria de ir ver o barco com ela, barco que, afinal, era dele. "Tu disseste que era teu" (p.32), ele diz. A mulher da limpeza responde que foi só porque havia gostado do barco. E o homem que agora tinha um barco: "Gostar é provavelmente a melhor maneira de ter, ter deve ser a pior maneira de gostar" (p.32). Essa frase, quisemos colocá-la assim: Gozar é a melhor maneira de ter, ter é a pior maneira de gozar.

O capitão do porto entrega as chaves à mulher da limpeza, enquanto o homem vai buscar a tripulação.

Os significantes, nesse capítulo, são os mesmos de anteriormente. Alguns dados se acrescentaram, mas isso tudo, só para o final.

6 Talvez pela própria atmosfera do conto, pensamos nessa última expressão, à parte a referência mais óbvia ao tempo das navegações portuguesas, como se remetesse aos autores do século XIX ver Herman Melville, Poe e outros), também eles procurando desvendar suas "ilhas desconhecidas".

\section{A limpeza do barco}

A mulher da limpeza vai ao barco e vale-se da advertência sobre as gaivotas, que defendiam seus filhos, e da vassoura que trazia do palácio. Mal havia ela subido à prancha e as gaivotas se precipitaram sobre ela. Após o combate, percebe a razão de sua fúria. Havia ninhos por toda a parte, alguns com ovos, outros abandonados (a maioria) e uns poucos com gaivotinhos de bico aberto, à espera da comida. Ela atira à água os ninhos vazios, mas deixa os outros onde estavam. Depois, examina o paiol das velas, verifica que, como o homem do barco, aprendia muito rápido e também já tinha a linguagem de marinheiro. Vê que algumas bainhas estão esgarçadas, porém, apenas as assinala, posto que as linhas que tinha da casa do rei não funcionariam ali: "[...] não podiam servir a linha e a agulha com que passajava as peúgas dos pajens antigamente, quer dizer, ainda ontem" (p.37). Viu que o paiol de munição estava vazio, mas preocupou-lhe mais a falta de munição de boca no paiol respectivo, afinal, "[...] não tarda que o sol se ponha, e ele a aparecer-me aí a clamar que tem fome, que é o dito de todos os homens mal entram em casa [...]" (p.39).

\section{A volta pelo barco}

No final das contas, as pessoas sempre se enganam em alguma coisa. A mulher da limpeza preocupou-se à toa, porque, ao deitar-se o sol, surgiu o homem no extremo do cais, portando um embrulho. Trazia alimento, mas não pôde trazer os marinheiros. Eles haviam recusado juntar-se a uma viagem que não sabiam aonde iria dar; além disso, como é sabido de toda a gente, já não há ilhas desconhecidas - e, se houvesse, não iriam arriscar-se em aventuras, como se estivessem no tempo do mar tenebroso ${ }^{6}$.

Respondeu-lhes o homem que tinha um barco que o mar é sempre tenebroso, mas não falou da ilha desconhecida, como quis a mulher, já que ainda não a conhecia (a ilha). A mulher da limpeza assinala que o mar não Ihe parecia tenebroso, mas ele chama sua atenção para o fato de que também as ilhas, às vezes, parecem flutuar, e não é verdade. "Que pensas em fazer se te falta tripulação, Ainda não sei, Podíamos ficar a viver aqui, eu oferecia-me para lavar os barcos e tu, [...], Tens com certeza um ofício [...]" (p.40). 
Um ofício, não havíamos nos dado conta, em que trabalha esse homem que, um belo dia, resolve ir ao palácio do rei pedir-lhe: "Dáme um barco". O homem responde que teve, que tem e que terá, mas quer antes saber quem é quando estiver na ilha desconhecida. "Se não sais de ti, não chegas a saber quem és" (p.40). O filósofo do rei sempre esteve a dizer essas coisas para a mulher, que todos os homens são uma ilha. Acontece que aquilo não era com ela, que era mulher.

Vão ver o barco, ela narra o que se passou à tarde, e o homem nota que ela também havia aprendido a linguagem de marinheiro, assim como ele havia aprendido. Concordam que, para aprender a navegar, três são os mestres, o céu, o mar e a água.

\section{O jantar, a falta de tripulação e a troca de olhares}

Fizeram, em pouco tempo, a volta pela caravela. "É bonita", disse o homem, "mas se eu não conseguir arranjar tripulantes suficientes para a manobra, terei de ir dizer ao rei que já não a quero" (pp.42-43).

A mulher diz que ele não deveria desistir na primeira dificuldade. Mas a primeira dificuldade foi ter ele esperado por três dias pelo rei. Ela diz que, se não encontrarem marinheiro, arranjam-se os dois, mas isso, na opinião do homem, é uma loucura. Resmungou por um tempo, até que chegassem à popa, onde fariam a refeição. Havia pão, um queijo duro, de cabra, azeitona e uma garrafa de vinho. Um jantar quase que sugestivo, se levarmos em conta que eram apenas os dois por ali (note-se que se fez questão do vinho, ao invés de água, simplesmente). Já a lua subia meio palmo sobre o mar, conforme nos narra, a sombra do mastro deitava sobre seus pés.

"É realmente bonita a nossa caravela, disse a mulher, e emendou logo, A tua, a tua" (pp.45 46).
O homem assinala que logo não será, se não arranjar tripulantes; ainda que o barco seja dele, deu-lho o rei, recorda a mulher. Enumeram-se as dificuldades, o homem a queixar-se e a mulher a consolá-lo. Em um certo ponto, o homem pergunta se a mulher está a rir-se dele, ao que ela contesta que não riria daquele que a fez sair pela porta das decisões.

Mas o que chama a atenção é que ele chegue a pensar que ela está a rir-se dele. E por que é que pensa isso? É que, por tanto se queixar, chega um momento em que ela estimula suas queixas e diz: "Evidentemente, depois teremos de esperar que seja a boa estação, e sair com a boa maré, e vir gente ao cais a desejar-nos boa viagem" (p.46).

Entretanto, no momento em que ela Ihe revela um atributo especial que ele possui e que move o desejo dela, porque alguém que faz com que outra pessoa tome alguma decisão, quanto mais de acompanhá-la, deve ter algo de especial, pelo menos para aquela pessoa, nesse momento, dizia, ergue os olhos e vê que o rosto dela está iluminado pelo luar, numa visão quase mística (somos nós que colocamos essa palavra no texto). "É realmente bonita, pensou" (p.47).

E o narrador comenta - "A mulher, essa, não pensou nada" (p.47). Assinala essa para pontuar bem de quem estamos a falar. Mas a mulher não pensou nada porque já havia pensado tudo durante os três dias, quando entreabria a porta para ver se aquele ainda continuava lá fora, à espera (a observação é do narrador, p. 47).

Temos aqui outra informação de que a mulher, sem ter o homem notado, já havia estado a dar atenção a ele. Isso tem uma importância, mas não queremos atropelar as coisas.

"Não sobrou migalha de pão ou de queijo, nem gota de vinho, os caroços das azeitonas
"Evidentemente, depois teremos de esperar que seja a boa estação, e sair com a boa maré, e vir gente ao cais a desejarnos boa viagem" 
foram atirados para a água, o chão está limpo como ficara quando a mulher da limpeza passou por cima o último esfregão" (p.47). Deve ser mesmo o único jantar do mundo, com pão e queijo, e sem prato, em que não sobram migalhas pelo chão.

Um paquete sai ao mar e solta um ronco potente, como devia ter sido os do leviatã (p.47), que, como sabemos, era um monstro da mitologia grega. Quer dizer que causouIhes medo, mas o que ocorre então? A mulher da limpeza comenta que, quando for a vez deles, farão menos barulho, e o homem: "Mas baloiçaremos mais" (p.48). Riem-se os dois. Remetamo-nos dessa cena para um estágio do desenvolvimento da criança que Lacan irá chamar de estádio de espelho. A criança, então, passa por um período em que apreende a imagem do espelho como tal, mas que, até que isso se estabeleça, coloca-a em uma relação especular com o mundo. Assim, "a criança que bate", afirma Lacan, "diz ter sido batida" (apud Dör, 1992, p. 79). Se nos reportarmos a um ensaio de Freud, intitulado "O Humor", veremos que ele, ali, narra uma outra situação, que iremos colocar aqui:

"Quando [...] o delinqüente, que pela manhã é conduzido à forca, expressa: 'É, já começou bem a semana' [...]" (Freud, 1999b, p.384).

Ele demonstra, depois, a forma como o que é imposto pelo mundo exterior é apreendido pelo sujeito para servir-lhe como forma de "escoamento" da energia investida (ou, como já está consagrado, catexisada).

Além disso, é importante notar com que elemento ocorre essa apreensão aqui. $\mathrm{O}$ elemento é a palavra "baloiçar", utilizada à maneira portuguesa e que, nós, brasileiros, reconheceremos como "balouçar". É um elemento sexual, não podemos deixar de admitir.

Após algum tempo em silêncio, um dos dois sugere que é hora de dormir. Mas não que estivessem com sono... Passam-se mais alguns instantes e descem para onde estão os beliches. Dirige-se um a bombordo, outro a estibordo, mas não sabemos qual foi cá e qual foi lá. $A$ mulher retorna e entrega ao homem uma vela, ficando ela com outra. Ao acenderem as velas, ele repara novamente na beleza dela. Ela, por sua vez, pensa: "Vê-se bem que só tem olhos para a ilha desconhecida" (Saramago, 1998, p.49). As pessoas se enganam mesmo.

Despedem-se, ele quis dizer-Ihe dorme bem, mas acabou dizendo - "Que tenhas sonhos felizes" (p.49), que é dizer a mesma coisa de outra maneira. Quando estiver sozinho, irá pensar em frases mais espirituosas, que é o que se espera de um homem quando está a sós com uma mulher (p. 50).

Ele começa a imaginar que estavam os dois em um barco muito grande, e que não se encontravam. Saramago narra:

O sonho é um prestidigitador hábil, muda as proporções das coisas e suas distâncias, separa as pessoas, e elas estão juntas, reúne-as, e quase não se vêem uma à outra, a mulher dorme a poucos metros e ele não soube como alcançá-la, quando é tão fácil ir de bombordo a estibordo (p.50).

\section{O sonho da ilha desconhecida}

Que é um sonho? O sonho, é o que sempre dizemos, é a realização de um desejo. Mas, e se esse desejo, no sonho, não se realiza? Lacan destaca esse ponto no livro 11 de seus Seminários, da seguinte maneira:

“Por que então sustentar a teoria que faz do sonho a imagem de um desejo, com este exemplo em que, numa espécie de reflexo flamejante, é justamente uma realidade que, quase decalcada, parece aqui arrancar o seu sonhante?" (1998, p.37).

Talvez, se o sonho não realiza o desejo, cria um mecanismo que assegure a realização de 
um desejo. Ora, isso, parece-nos, já está implícito em toda a obra de Freud(1999 ${ }^{2}$ ). No sonho da injeção de Irmã, por exemplo, o que ocorre? É quando a situação se torna angustiante que há uma virada que permite a realização do desejo. No sonho a que Lacan se refere, a idéia é outra. O filho se levanta e vai ao pai - que se encontra deitado - e diz-lhe: Pai, não vês que estou queimando? Em primeiro lugar, o sonho realiza o desejo do pai de que o filho continuasse vivo, ou como expressa Freud: "No sonho, a criança morta se comporta como um vivente [...]" (1999a, p. 514). Até aí, as coisas correm bem, mas ela vem e diz que está queimando, isso causa um sentimento de angústia, e é para livrar-se do sentimento de angústia que o pai acorda. É assim que ocorre nos pesadelos. Em outros sonhos, em contrapartida, que não chegam a ser pesadelos, também sonhamos que sonhamos. Eé aqui que, defendemos, expressa-se toda a genialidade desse conto de Saramago. Porque o sonho éo leitor esteja atento - uma metalinguagem. Que é uma metalinguagem? É quando, em uma peça de teatro, por exemplo, ocorre uma outra peça de teatro, que diz alguma coisa sobre a primeira. E em que momento ocorre a metalinguagem em Saramago? É justamente no momento em que o desejo do homem não pode mais ser realizado, as coisas parece que vão mal - a mulher vai para um lado, ele, para o outro ${ }^{7}$.

Creio que, para apreendermos o significado do sonho, seja necessário lê-lo por inteiro, para depois analisá-lo. Fazemos aqui, por isso, um breve resumo, pois o sonho é demasiado grande, e seria melhor, de outra maneira, reproduzi-lo na íntegra.

O homem então sonha que está em alto mar, que tem a sua tripulação, mantimentos e coisas suficientes para habitar a sua ilha desconhecida. Descobre, contudo, que não está ali a mulher. A tripulação resolve descer em uma ilha povoada e o homem se vê sozinho em seu barco, que mais parece uma floresta. Ele então sai a ceifar algumas espigas e percebe uma sombra ao seu lado.

Em primeiro lugar, vê-se que o desejo de ir em busca da ilha desconhecida se realiza. Mas não é só isso, ele se realiza como se realiza o desejo de uma criança de ser grande, por isso: "Sonhou que sua caravela ia no mar alto, com as três velas triangulares gloriosamente enfunadas, abrindo caminho sobre as ondas, enquanto ele manejava a roda do leme" (Saramago, 1998, p.53).

Temos, ainda, que sua tripulação aí está. Fazem-se aqui presentes, então, os "restos diurnos" que também se expressam como realizações do desejo. São eles: os tripulantes, como já vimos, os mantimentos e coisas para habitar a ilha. Que mantimentos traz? Traz mais do que se poderia supor. Traz animais, patos, coelhos, galinhas; mas para quê ele traz esses animais? Porque imagina que a ilha desconhecida pode ser, como o foi tantas vezes no passado, deserta. São, portanto, símbolos da fertilidade. Traz ainda cavalos, bois e asnos. A tripulação não é composta só por homens.

"[...] de súbito, o vento deu uma guinada, a vela maior bateu e ondulou, por trás dela estava o que antes não se vira, um grupo de mulheres, que mesmo sem as contar se adivinha serem tantas quanto os marinheiros [...]" (p.54).

Há tantas mulheres quanto tripulantes, mas falta uma mulher, a que corresponderia ao homem que vai ao leme. Ele tenta imaginar onde ela está, mas lembra-se que ela, à ultima hora, resolveu não vir, despediu-se dizendo Adeus, adeus, já que só tens olhos para a ilha desconhecida (p.55). E não é verdade, justo agora está ele a procurá-la com os olhos.

"Neste momento, o céu cobriu-se e começou a chover, e, tendo chovido, principiaram a brotar inúmeras plantas das fileiras de sacos de terra alinhadas ao longo da amurada [...]" (p.55).
7 Será necessário recordar que o sonho é o lugar do absurdo, a instância psicótica da vida normal, diria Freud. Todo sonho funciona como realizador de um desejo, mas é de se espantar que, para tanto, não siga uma seqüência lógica, ou melhor, o sonho é sempre inconseqüente. Nesse sentido, podemos até mesmo afirmar que o sonho é atemporal, mas que, na medida em que é apreendido pelo Eu, na lembrança do sonho, torna-se cronológico, mas, todavia, inconseqüente, ou ilógico. Para Freud (1999a), isso ocorre pelo trabalho de censura do sonho, mas cabe a nós também analisarmos um outro ponto. Se o sonho é o rg a n $i z$ a d cronologicamente pelo Eu, ocorre que as regras para a realização do desejo deveriam ser as mesmas da vida desperta, mas, por essas regras, tal realização seria impossivel, além de insuportável; propomos, pois, que os mecanismos do sonho propiciam a realização do desejo pelo absurdo, o que também serve ao propósito do Eu de "proteger-se" da angústia pela realização de um desejo inconsciente. 
Trouxe plantas, e sacos de terra, também. Não porque se suspeite que não haja terra bastante na ilha, mas para que se ganhe tempo.

Não basta o homem descobrir a ilha desconhecida, saber quem é nela, ele tem de habitá-la como se fosse a sua terra natal.

Os tripulantes, então, avisam-no que descerão na primeira ilha habitada que encontrarem.

O homem reclama que não poderá governar sozinho. Mas disso ele não se havia lembrado quando resolveu aventurar-se de barco por aí, atrás da ilha desconhecida.

"A ilha desconhecida é coisa que não existe, não passa duma idéia da tua cabeça, os geógrafos do rei foram ver nos mapas e declararam que ilhas por conhecer é coisa que se acabou desde há muito tempo" (pp.56-57).

O homem irrita-se e diz-Ihes que deveriam ter ficado na cidade. Surge uma ilha e os homens querem que pare. Não é preciso, a caravela virou a proa em direção à terra. O homem livra-se de seus opositores, finalmente. Levam consigo, no entanto, quase tudo que ali havia, os animais, as mulheres... Até as gaivotas, em um gesto nunca antes possível, portam no bico os seus gaivotinhos. No atropelo, derramam os homens as sacas de terra, a caravela era um campo lavrado. Crescem as árvores, e já não se precisa mais de velas. Começam a cantar pássaros. O homem, então, trava a roda do leme, "desce ao campo com a foice na mão, e foi quando tinha cortado as primeiras espigas que viu uma sombra ao lado da sua sombra" (p. 62). Daí em diante, conhecemos a história. O que ocorre? O sentimento de completude, que não se sabe se um está a bombordo ou a estibordo, se o beliche é desse ou daquele, ou se há mesmo os dois beliches. Não tanto pelo componente sexual aí inserido - no caso, o gozo de ser - mas o que devemos apontar é para todas aquelas coisas que o sujeito levava para a ilha desconhecida. É como dizíamos no começo desta exposição, o sonho é uma metalinguagem e vem a dizer tudo sobre o resto do conto. O bom entendedor já encontrou aqui sua meia palavra. Por isso, terminaremos esta exposição assim:

"Pela hora do meio dia, com a maré, A Ilha Desconhecida fez-se enfim ao mar, à procura de si mesma" (p.62).

\section{Conclusão}

Naturalmente, existem aí vários elementos que deixamos escapar, um tanto de propósito. Alguns bastante óbvios, é verdade. Que o homem tenha dito à mulher que tivesse bons sonhos, ao invés de dizer durma bem, como afirma ser o que realmente queria dizer, é algo que não podemos deixar de lado. Tanto mais porque ele pensa, após, em ditos espirituosos. Ora, desde que o século vinte nasceu, não existe, ao senso comum, dito mais espirituoso do que - Tenha bons sonhos. E ainda que ele tenha de ceifar as espigas antes de poder juntar-se à mulher.

Queremos iniciar a conclusão retomando os quatro significantes que apontamos:

o rei;

o barco;

- a mulher da limpeza;

o cartão do rei.

Pensamos que trabalhar um a um, em toda a sua extensão, seria errôneo, ainda que, em certo sentido, fértil. De modo geral, cremos que trará menos esclarecimento. Estejamos atentos em como eles se relacionam, sobretudo porque, se viéssemos, aqui, entregar ao leitor a fórmula geral, se disséssemos: "Olha, o rei corresponde ao Pai, o barco ao falo, a mulher da limpeza é a mãe, o cartão do rei é o Nome-do-Pai, e a ilha 
desconhecida é o Outro", isso faria algum sentido? Não cremos, pelo contrário, seria, de certo modo, trair Lacan, e mais, trair Freud, no sentido mesmo que, ao estabelecer tais ligações, estaríamos ignorando aquilo que há de mais importante no contexto psicanalítico, a singularidade na constituição do sujeito.

Tudo que até agora analisamos leva-nos a crer que justamente o que expusemos pode corresponder a uma boa interpretação do conto, mas queremos fazer explorar mais, queremos mostrar como isso faz sentido. Retomamos, então, a reflexão desde o princípio.

Repare o leitor que, no primeiro capítulo, atentamos para o significante barco, para o processo metonímico e para uma função que estaria por trás da função do rei. Essa função do rei é a função paterna. O rei é a metáfora para o Pai, sua função é uma metáfora para a função paterna. Qual a função paterna? O Pai é uma metáfora, diria Lacan. O Pai é a lei. Mas o que o filho vai pedir ao pai? É o falo, é ser grande, que é a fantasia que toda criança tem. Pois bem, a função paterna não é, por conseguinte, apenas a de instituir a lei, é a de atender ao desejo do filho. O homem, então, vai à porta do rei e pede-lhe um barco. Seja qual for o pedido feito, a função do rei é ir à porta, receber o pedido, e despachar sim, ou não, conforme for de maré.

No caso do homem que queria um barco, contudo, as coisas não se passaram bem assim. O homem, ao invés de pedir logo o que queria, disse querer falar ao rei. Ora, que faz ele, então? Não é recobrar as coisas ao seu sentido próprio? Não é por isso que as coisas parecem andar mal? É que o que ele pede é simplesmente que cada um cumpra o seu papel.
O rei, por três dias, ignora o pedido para ir atender ao homem, e só quando a mulher da limpeza deixa de atender ao rei para ir ver como está o suplicante é que o rei, irritado, vai ver o que quer o homem. Recobramos aqui, onde aparece isso:

"No caso que estamos narrando, o resultado da ponderação entre benefícios e prejuízos foi ter ido o rei, ao cabo de três dias, e em real pessoa, à porta das petições" (p.11). Esse é o primeiro sinal; o segundo segue abaixo:

"A mulher, essa, não pensou nada, devia ter pensado tudo durante aqueles três dias, quando entreabria de vez em quando a porta para ver se aquele ainda continuava lá fora, à espera" (p.47).

Assim, o rei corresponde ao pai, a mulher da limpeza, à mãe, e o pedido por um barco corresponde ao pedido por um falo. Mas o que é esse falo? O falo não é o causador do desejo, mas é, ele também, uma metáfora. É o falo que mantém o desejo, que é o desejo da mãe. Por isso, a função paterna é a de fornecer o falo que permitirá manter o sujeito ligado à mãe. Acontece que, de alguma forma, isso não se realiza quando o homem recebe o barco, ainda que o barco que receba tenha sido, coincidentemente, o que a mulher da limpeza desejava.

Nesse instante, então, quando o homem se sente novamente separado da mulher, é que surge o sonho da ilha desconhecida. E que é o sonho da ilha desconhecida, com todos aqueles significantes que servirão para ocupála? Não nos arriscamos a uma tal tradução, achamos que Freud o faria muito melhor, e o faria dessa forma: wo es war, soll Ich werden. O termo "Ich", que aparece em letras maiúsculas, refere-se ao termo psicanalítico, 
e não à categoria gramatical. Assim, onde havia antes o desejo, o "eu" deve se fazer presente, ocupar o seu lugar.

Queremos retornar, agora, ao instante em que o homem recebe o cartão de visitas do rei. Nesse instante, ele olha para o cartão e vê escrito Rei, por baixo do nome do rei. O leitor poderá, se quiser, fazer o seguinte: tomar duma folha em branco e escrever nome do rei, traçar uma linha abaixo disso e, por baixo dessa linha, escrever Rei. Acho que as coisas ficam mais claras dessa maneira (ver Saussure, 1992, e Dör, 1992, a respeito do corte do significante).

Que é o rei, senão aquele que tem poder? Muito sutilmente, no entanto, é o único momento, no conto inteiro, repetimos, em que a palavra rei aparece escrita dessa forma: Rei. Com a letra maiúscula, o que é uma diferença. É quando o rei entrega seu nome ao homem, que irá com ele à doca receber o barco. Em seguida, a mulher da limpeza está a olhar com cara de caso para o homem que desce o degrau da porta. Aqui, ficamos sabendo mais tarde, foi o instante em que a mulher da limpeza decide ir atrás do homem. Por que, se o rei corresponde ao pai, o homem o subjuga o tempo todo a seus caprichos? Enfrenta-o e diz, quando o rei anuncia que não lhe fornecerá um barco: Darás. Não será muito difícil deduzir. O desejo que o sonho está aqui para realizar, o de reencontro com o Outro, o reencontro com a Mãe, só será possivel se o homem transpuser a lei, se for maior que a lei, ou melhor, se ele, de alguma maneira, se tornar a lei. E já na primeira linha do conto, isso se faz presente: "Um homem foi bater à porta do rei e disse-lhe, Dá-me um barco".
Quando o homem vai à doca, ocorre outro processo metonímico. A função paterna é atribuída ao capitão, que não dará o barco simplesmente. Acaba, contudo, por fornecê-lo, e acaba por fornecer, precisamente, aquele barco que o sujeito crê que será o barco perfeito. É o barco que a mulher desejou. Conforme narra Saramago:

"É um barco com muita experiência, ainda do tempo em que toda a gente andava à procura de ilhas desconhecidas" (p.28). Em seguida, ouvimos a mulher da limpeza gritar: "É o meu barco"(p.28).

Lacan, em seu seminário sobre o sujeito da certeza, diz o seguinte:

"O pai, o Nome-do-Pai, sustenta a estrutura do desejo com a da lei - mas a herança do pai é aquilo que nos designa Kierkegaard, é seu pecado" (1998, p.38).

Que é o pecado do pai? O pai não é o limite entre a criança e a mãe? Não é um limite que o próprio pai transpõe, ele mesmo? Pois esse é o barco experiente, a herança paterna, que irá servir de acessório para que o homem se torne, novamente, o desejo da mãe.

Eis, então, o desejo que o sonho satisfaz, ainda que não por completo, o de re-união com a mãe. Não deve ser à toa que o conto se chama o Conto da Ilha Desconhecida, posto que a ilha seja o elemento necessário para a realização do desejo. Como dizíamos, o rei corresponde ao pai, a mulher da limpeza, à mãe, a ilha desconhecida, ao Outro, e o cartão do rei corresponde à metáfora do Nome-do-Pai. 
DÖR, Joel. Introdução à Leitura de Lacan: o Inconsciente Estruturado como Linguagem. Porto Alegre: Artes Médicas, 1992.

FREUD, S.. Der Humor. In Freud, Sigmund. Werke aus den Jahren 1925-1931. Frankfurt: Fischer Taschenbuch Verlag, 1999b. (Gesammelte Werke, v. 14).

Die Traumdeutung. Frankfurt: Fischer Taschenbuch Verlag, 1999a. (Gesammelte Werke, v. 2-3).

Das Unbewusste. Frankfurt: Fischer Taschenbuch Verlag. (Gesammelte Werke, V. 10), 1999 b.

HERGENHAHN, B. R.. An Introduction to the History of Psychology. Belmont: Wadsworth, 1986, 443p.

LACAN, J. Escritos. v. 1, 12 ed. México: Siglo Veintiuno Editores, 1984 1984

Escritos. v. 2, 12 ed. México: Siglo Veintiuno Editores,

O Seminário, livro 11: os Quatro Conceitos Fundamentais da Psicanálise. Texto estabelecido por JaquesAlain Miller. 2 ed. Rio de Janeiro: Jorge Zahar Editor, 1998. (Campo Freudiano no Brasil).

MUELLeR, Fernand-Lucien. História da Psicologia: da Antiguidade aos Dias de Hoje. São Paulo: Companhia Editora Nacional, 1978.

SARAMAGO, José. O Conto da Ilha Desconhecida. São Paulo: Companhia das Letras, 1998.

SAUSSURE, Ferdinand de. Curso de Lingüística Geral. Lisboa: Publicações Dom Quixote, 1992, 392 p. 